\title{
The Link between Venture Capital Supply Factors and Economic Development in South Africa
}

\author{
Pumela Msweli \\ University of Limpopo, Faculty of Management and Law \\ Private Bag X1106 Sovenga 0727, South Africa \\ Email: pumela.msweli@ul.ac.za
}

Olabanji Oni

University of Limpopo, School of Economics and Management, Department of Business Management, Private Bag X1106 Sovenga 0727, South Africa

Email: Olabanji.Oni@ul.ac.za

\section{Doi:10.5901/mjss.2014.v5n9p18}

\begin{abstract}
The purpose of this paper is to provide a new theoretical model for the factors that influence the supply of venture capital investment in South Africa. Based on extant literature, the study puts forward a tentative framework to explain the link between venture capital supply factors and economic development. To this point, the paper has established that there is a link between venture capital supply and economic development and the link is mediated by formal job creation in the MSME sector. The framework depicted in Figure 4 shows three key determinants of venture capital supply including the MSME density, the extent to which industrialisation has taken place and the share of natural resource contribution to GDP. While the utility of the framework is limited without empirical evidence, the study draws attention to the need of the South African economy to find mechanisms of increasing formal job creation in the small and medium enterprise sector while simultaneously focusing on increasing the rate of industrialising the economy.
\end{abstract}

Keywords: Venture capital; SMEs; Industrialisation and Job creation.

\section{Contextual Background}

Private equity and venture capital funds are a type of fund that make investments in innovative small and medium enterprises (SMEs). Private equity funders and venture capitalists usually finance a small business entity by providing seed, start-up or expansion fund (Mishkin, 2013). Venture capitals are privately raised external equity capital used to fund early stage firms with attractive growth prospects. Angel capitalists tend to be investors who do not actually operate as a business but invest in promising early stage companies in exchange for a portion of the firm's equity (Gitman 2010).

According to Snieska and Venckuviene (2009) venture capital and private equity are the most attractive source of finance for financing new technology based firms. Additionally, Memba, Gakure and Karanja (2012) found that venture capital has led to an increase in SME growth in Kenya. Furthermore, Johnson and Sohl (2012) found that venture backed initial public offering (IPO) firms outperform non-venture backed IPO firms in terms of operating performance.

The South African Venture Capital and Private Equity Association (2008 )report points out that the private equity industry in South Africa was boosted by the large number of leveraged buy outs (LBO) and management buy outs (MBO), resulting from the widespread disinvestment of multinationals from South Africa in the 1980s. According to Watkins (2008) private equity was a significant asset class in South Africa with a large number of multibillion rand deals concluded in 2007. Watkins (2008) attributes private equity growth in South Africa to the low debt to equity ratio in comparison to America and Europe.

In a typical private equity deal in South Africa, a private equity firm buys a company, using some of its own money and some borrowed money with the aim of improving the performance of the acquired company. The acquisition is made with an eye towards cashing out and/or with the aim to comply with the Black Economic Empowerment legislation. The introduction of the Broad-Based Black Economic Empowerment (BEE) legislation in 2003, and subsequent implementation of the B-BBEE Codes of Good Practice in 2007 resulted in an increase in the number of private equity deals in South Africa (SAVCA, 2012). 


\section{A Framework to Explain the Link Between Venture Capital Supply and Economic Development}

In the past 20 years, scholars have fervently pursued studies that look into the link between private equity and venture capital funding with economic development. For example Jeng and Wells (2000) investigated the determinants of venture capital funding in 21 countries and found that over time IPO's are the main force behind cyclical swings in venture capital. Van Deventer \& Mlambo (2009) found that the three most important criteria for South African venture capitalists are the entrepreneur's honesty and integrity, a good expected market acceptance and a high internal rate of return (IRR).

A number of studies (Qian\& Zhang 2008; Masum, Simiyu, Ronoh, Daar \& Singer, 2010; Hadi, Curt\&Tyge-Payne 2008) concur with the notion that private equity and venture capital firms serve as financial intermediaries in a market where lenders and borrowers find it costly to get together. As pointed out by Mishkin (2013) the costs are due to adverse selection and moral hazard as well as the cost of gathering information about the investee company. Additionally, private equity and venture capital funding provides innovators and entrepreneurs with an opportunity for creating new products while simultaneously benefiting from the management expertise of venture capitalist.

There are four factors identified in literature that are likely to influence the supply of venture capital in South Africa. These include (a) Size of micro, small and medium enterprise; (b) natural resources; (c)the extent to which the economy is industrialised; and (d)governance and corruption. Each of these factors is discussed in turn.

\subsection{Size of micro, small and medium enterprises(MSME)}

As pointed out in the World Bank's Global Economic Prospects (2012) report, 90 per cent or more of the world's businesses are classified as SMEs. In Africa, where poverty and unemployment levels are high, the potential for strengthening the SME sector using venture capital is considerable, provided that barriers such as red tape to start small business, access to finance and problems associated with technological divide are overcome. Jeng and Wells (2000), state that venture capital backed enterprises show higher revenue growth in comparison to non-venture capital backed entities. However, the pull factor for venture capital funds is likely to depend on the density of the micro, small and medium enterprises in the economy

According to Kungolo (2010), in South Africa, small and medium enterprises account for about $91 \%$ of the formal business entities, contributing between 50 and $57 \%$ of GDP (Kungolo, 2010). A study by the Competition Commission (2004) estimated that $99.3 \%$ of South African businesses were SMEs and that these SMEs accounted for $53.9 \%$ of total employment and contributed 34.8\% to GDP, (NCR, 2011). The World Bank 2010 MSME Indicator Country Report, which records the number of formally registered MSMEs across 132 economies, shows a link between the structure of the MSME sector and job creation. The study showed that formal MSMEs employ more than one-third of the global population, contributing around 33 percent of employment in developing economies (World Bank, 2010). The study also showed that in regions where the informal sector is large, the ratio of formal MSME to total employment is low.

This study postulates that an economy with a large proportion of the formal sector compared to the informal sector (MSME density) is likely to attract more venture capital funding into the SME sector. This means that for the South African economy to grow in a sustainable fashion, it needs to increase the propensity to create jobs in the MSME sector. Aside from the facts mentioned above, SMEs have established a successful track record globally in nurturing entrepreneurship and innovation, and serving as attractive ventures for foreign investment (Raynard and Forstater, 2002). From the socioeconomic development viewpoint, SMEs are uniquely structured to adapt easily to market conditions. Moreover, they can withstand adverse economic conditions with their flexible structure. Additionally, SME's are more labour intensive than larger firms and they have lower capital costs associated with job creation. Figure 1 illustrates the connections highlighted between size of informal sector, ratio of formal MSME to total employment, and economic development.

Figure 1: Micro, Small and Medium Enterprises and Venture Capital Supply

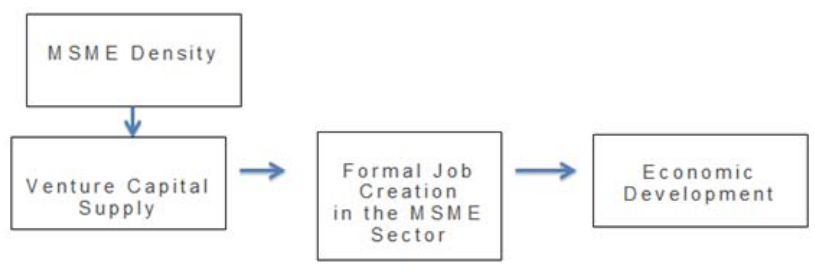




\subsection{Natural resource contribution to GDP}

The International Monetary Fund (IMF) predicts that Africa will be among the top ten of the highest growing economies in the world by 2015 (cited in Economist, 2011). Growth in the Sub-Sahara Africa region is at 5.5 percent with over a third of countries growing by 6 percent or more (World Bank, 2013). The positive economic outlook of Sub-Sahara Africa is attributed to the commodity boom led by China in the late 1990's as well as increase in public sector spending on infrastructure. Africa continues to be the world's largest producer of platinum and coal (Simpson, 2012). Nigeria and Angola are among the top 20 oil producers in the world (Nguyen, 2012). These statistics show that the global demand for resources supplied by Sub-Saharan Africa is not likely to diminish in the near future.

In South Africa there are seven subsectors within the mining sector. These include coal, platinum, iron ore, gold, diamonds, chrome, and diverse mining subsectors. Platinum is the largest subsector with a market capitalisation of R277,57 billion, followed by gold with market capitalisation of R223,27 billion (SENS, 2012). The diamonds sector is the smallest with a market capitalisation of R203 million (SENS, 2012).

With the signing of the Declaration on strategy for sustainable growth and transformation in the mining industry by the mining sector stakeholders in 2010, it was agreed that ownership in the sector should be opened up for black economic empowerment transactions. Taken together with the beneficiation strategy released by the South African government in 2011 natural resources are discernibly a magnet to attract venture capital and private equity funding, especially in the context of the requirement to comply with the black economic empowerment legislation. In the light of the discussion above, the study makes a connection between venture capital supply and contribution of natural resources to GDP as illustrated above. Figure 2 illustrates the connection.

Figure 2: Linking the share of natural resource to GDP and Venture Capital Supply

Share of natural resource contribution to GDP
Venture Capital Supply

\subsection{The extent to which the economy is industrialised}

As illustrated in Table 1 the South Africa economy is well diversified. However, it faces structural challenges. Growth has been driven by consumption, which saw growth in GDP of the Wholesale and Retail sector surge.

Table 1: Annualised Quarterly Change in GDP by Industry R million (at constant 2005 Prices Seasonally Adjusted)

\begin{tabular}{|l|c|c|c|c|c|c|c|c|}
\hline & $\mathbf{2 0 0 3 - 2 0 0 4}$ & $\mathbf{2 0 0 4 - 2 0 0 5}$ & $\mathbf{2 0 0 5 - 2 0 0 6}$ & $\mathbf{2 0 0 6 - 2 0 0 7}$ & $\mathbf{2 0 0 7 - 2 0 0 8}$ & $\mathbf{2 0 0 8 - 2 0 0 9}$ & $\mathbf{2 0 0 9 - 0 1 0}$ & $\mathbf{2 0 1 0 - 2 0 1 1}$ \\
\hline Agriculture & 1240 & 4088,1 & $-8171,9$ & 3768 & 26382233,5 & $-26361621,1$ & 701,1 & $-197,9$ \\
\hline Mining & 6241,7 & 4306,4 & $-2510,5$ & $-114,3$ & 25937522,4 & $-25982635,7$ & 21303,4 & 1155,7 \\
\hline Manufacturing & 45536 & 60545,2 & 66724,4 & 57854,3 & 24800297,7 & $-24890391,2$ & 59145,4 & 40894,9 \\
\hline Construction & 11504 & 16428 & 16096 & 25556 & 24437060,8 & $-24403830,8$ & 1714 & 1112 \\
\hline Wholesale \& Retail & 37319,2 & 51349 & 46495,2 & 43883,8 & 23549935,2 & $-23552067,5$ & 33054,5 & 40265,7 \\
\hline Transport, \& Logistics & 24688 & 28051,2 & 28540,8 & 38728 & 22916210,7 & $-22885368,8$ & 13255,7 & 20944,1 \\
\hline Finance, \&Services & 73684 & 63840,4 & 113991,6 & 101996 & 21493274,5 & $-21375330,5$ & 32660 & 61392 \\
\hline
\end{tabular}

Source: Based on calculations done on the basis of data obtained from Statistics South Africa 2012

As pointed out in the IPAP (2011), public infrastructure investment has been a key driver of the industrialisation of the South African economy. The extent to which an economy is industrialised is often measured by the economy changes depicting the share of the manufacturing sector in relation to the share of the agricultural sector (Brown, 2005). This study puts forward a contention that the share of the manufacturing sector in relation to the agricultural sector will have an influence on venture capital supply. Venture capitalists are likely to play a huge role in fueling the growth of industrialisation by creating jobs in the small and medium enterprises involved in manufacturing. Figure 3 illustrates how industrialisation is connected to venture capital supply and economic development. 
Figure 3: Linking venture capital supply to industrialisation and economic development

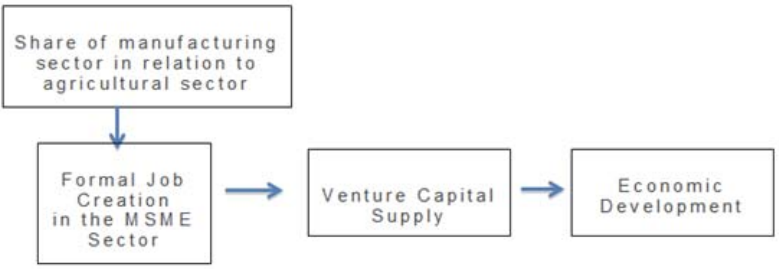

\subsection{Governance and Corruption}

The South African National Development Plan cited high levels of corruption as one of the root cause of poor economic performance. The International Corruption Perception Index (CPI) has been used to score countries on a scale of 0 (highly corrupt) to 100 (very clean). In 2012 Transparency International Corruption Perception Index ranked South Africa $69^{\text {th }}$ out of 176 countries on corruption. As illustrated in Figure 4, venture capital supply is determined by how the country is perceived with respect to governance and corruption. The paper argues that venture capitalists are likely to direct their investments to countries where principles of good governance are upheld in order to protect their investments.

Figure 4 presents the framework that highlights the link between venture capital supply and economic development. The figure shows that MSME density, share of natural resources to GDP contribution and share of manufacturing sector to agricultural sector affect the supply of venture capital. All factors being equal venture capital supply has a high propensity to create formal jobs in the small and medium enterprise sector, thus contributing to economic development.

Figure 4: A framework that links venture capital supply and economic development

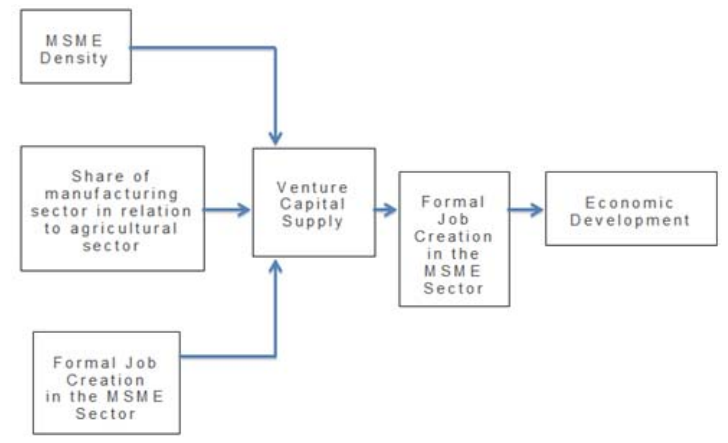

\section{Conclusion and Avenues for Further Research}

To this point, the paper has established that there is a link between venture capital supply and economic development and the link is mediated by formal job creation in the MSME sector. The framework depicted in Figure 4 shows three key determinants of venture capital supply including the MSME density, the extent to which industrialisation has taken place and the share of natural resource contribution to GDP. While the utility of the framework is limited without empirical evidence, the study draws attention to the need of the South African economy to find mechanisms of increasing formal job creation in the small and medium enterprise sector while simultaneously focusing on increasing the rate of industrialising the economy.

The framework warrants further research on additional determinants on venture capital supply in the context of the sub-Saharan dynamics where there is shortage of skilled workforce, high inequality and poverty levels. 


\section{References}

African Development Bank (2012). African Development Bank: 18 million dollars to finance sub-Saharan infrastructure. [Online] Available:www.afdb.org. (July 11, 2013).

Brown, S. (2005). Conflict and Governance: Economic Transformation Audit. Institute for Justice and Reconciliation: Cape Town. $21-27$.

Economist (2011). A more hopeful continent: The lion kings? Africa is now one of the world's fastest-growing regions. Jan 6, Print Edition. [Online] Available: www.economist.com/node/17853324. (July 12, 2013).

Industrial Policy Action Plan (2010). Economic Sectors and Employment Cluster.

Jeng Leslie A \& Wells, Philippe C (2000). The determinants of venture capital funding: evidence across countries. Journal of Corporate Finance, 6, 241-289.

KPMG SAVCA Survey (2012). Venture Capital and Industry Performance Survey of South Africa.[Online] Available: www.savca.co.za. (June 10, 2013).

Kungolo, M. (2010). Job creation versus job shedding and the role of SMEs in economic development. African Journal of Business Management, 4.(11): 2288-2295

Li Y. \& Mahoney J.T. (2011). When are venture capital projects initiated? Journal of Business Venturing, 26: 239 -254.

Mishkin Frederick S (2013). The Economics of Money, Banking, and Financial Markets. New Jersey:Pearson Prentice Hall.

Masum H., Chakma J., Simiyu K., Ronoh W. Daar A.S., and Singer P.A. (2010). Venture funding for science-based African health innovation. BMC International Health and Human Rights, 10 (Suppl 1): S12.

National Credit Regulator (2011). Literature Review on Small and Medium Enterprises' Access To Credit And Support In South Africa. [Online] Available: http://www.ncr.org.za/pdfs/Literature\%20Review\%20on\%20SME\%20Access\%20to\%20Credit\%20in\%20South \%20Africa_Final\%20Report_NCR_Dec\%202011.pdfW. (June 10, 2013).

Nguyen, L (2012). OPEC Oil Prōuction Rises as Angola and Nigeria Pump More. Bloomberg, September 11. [Online] Available: www.bloomberg.com/news/2012-09-11/opec-oil-production (July 14, 2013).

Park H.D.\&Steensma K. (2012). When does corporate venture capital add value for new ventures? Strategic Management Journal, 33,122.

Qian P. \& Zhang W. (2008).Rate of return on venture capital investment in China. China Economic Journal. 1(2), pp155-164.

Raynard P.\& Forstater M. (2002) Implications for Small and Medium Enterprises in Developing Countries, United Nations Industrial Development Organization. [Online] Available: http://www.unido.org. (May 8, 2012).

Rubin J.S. (2009). Developmental venture capital: conceptualizing the field. Venture Capital, 11 (4), pp335-360.

Simpson S.D. (2012). A Deeper Look at South Africa's Commodity Industry. Commodity HQ, October 30. [Online] Available: commodityhq.com/2012/a-deeper-look-at-south-africas. (July 13, 2013).

Statistics South Africa. (2012). Census 2011. [Online] Available: www.statssagov.za/publications. (April 15, 2013).

Van Deventer B. and Mlambo C.(2009). Factors influencing venture capitalists' project financing decisions in South Africa. South African Journal of Business Management, 40, pp33-41.

KhrystynaKushnir, Melina Laura Mirmulstein, and Rita Ramalho(2010). World Bank MSME Country Indicator Report: Micro, Small, and Medium Enterprises Around the World: How Many Are There, and What Affects the Count? [Online] Available: http://www.ifc.org/wps/wcm/connect/9ae1dd80495860d6a482b519583b6d16/MSME-ClAnalysisNote.pdf?MOD=AJPERES\&CACHEID=9ae1dd80495860d6a482b519583b6d16. (October 10, 2013).

Word Bank Indicators (2013). Human Development Index by country. [Online] Available: http://data.worldbank.org/indicator INY.GNP.PCAP.PP.CD. (May 26, 2013).

United Nations (2011). World Economic Situation and Prospects 2012:GlobalEconomic Outlook. [Online] Available: www.un.org/.../policy /wesp/wesp_current/2012wesp_prerel.pdf. (May 26, 2013). 